\title{
Excavation, Inheritance and Development About Jiaodong Red Culture Gene
}

\author{
Qiong Zhang
}

\author{
Shandong Technology and Business University \\ Email: yuqingcool423@163.com
}

\begin{abstract}
As the core of China's socialist advanced culture, red culture is a special cultural type accumulated by the Chinese people under the leadership of the Communist Party of China in the long-term revolution and construction. It contains rich revolutionary spirit and profound historical and cultural connotation. It is a valuable spiritual wealth of the Chinese Communist Party and the Chinese people. By analyzing the connotation and characteristics of Jiaodong red culture, this paper summarizes the significance of inheriting Jiaodong red culture, and extracts the requirements of developing and carrying forward Jiaodong red culture from four levels.
\end{abstract}

Keywords: Jiaodong, Red culture gene, Socialist country, Chinese revolution.

\section{INTRODUCTION}

Jiaodong's red culture has profound deposits and rich resources. Strengthening the excavation, inheritance and development of red culture is an important content to strengthen the study and education of party history and strengthen the people's ideals and beliefs. It is also an important way to strengthen the road, theory, system and culture confidence of socialism with Chinese characteristics. Jiaodong revolutionary spirit and other national and local spirits, such as Jinggangshan spirit, Yan'an spirit, Xibaipo Spirit and Yimeng spirit, have both similarities and characteristics ${ }^{[1]}$. Only by summarizing and exploring these characteristics can Jiaodong revolutionary spirit have long-term vitality. Through the systematic excavation and sorting of relevant materials of Jiaodong red culture and the detailed and in-depth research on the specific fields of Jiaodong red culture, we can condense Jiaodong culture that can better reflect the characteristics and unique characteristics of Jiaodong red culture, and promote the excellent culture of the Chinese nation, the advanced culture of Marxism ${ }^{[2]}$. The revolutionary culture of Communists has been effectively inherited and developed in the journey of realizing socialist modernization and strengthening the country.

\section{CONNOTATION AND CHARACTERISTICS OF JIAODONG RED CULTURE}

Jiaodong, Shandong peninsula east of Jiaolai river. Jiaodong culture is a regional culture formed and developed since human beings in Jiaodong. It has experienced five development stages: Jiaodong primitive culture, Jiaodong Qi culture, Jiaodong feudal social culture, Jiaodong modern and contemporary culture. In the modern and contemporary cultural development stage of Jiaodong, Jiaodong red culture with historical influence was formed during the agrarian revolution, the war of resistance against Japan and the war of liberation. In the 28 years from the beginning of the Communist Party's activities in 1921 to October 1949, Jiaodong party organization has experienced an extraordinary process of creation, growth, development and growth, interpreted moving heroic stories one after another, and woven Jiaodong red culture with fresh historical facts.

\subsection{The connotation of Jiaodong red culture}

Jiaodong red culture refers to the advanced culture jointly created by the Communist Party of China and Jiaodong people and other advanced elements in the process of leading the revolutionary struggle of Jiaodong people ${ }^{[3]}$. The specific contents should include the party's leadership over Jiaodong people, the party's 
political power construction, base area construction and cultural construction in Jiaodong.

The research on Jiaodong red culture includes not only the research on multi-level and multi-faceted specific problems and specific fields, but also the macro refining and refining of Jiaodong spirit. With vivid, concise, vivid and lively language, we strive to reflect the characteristics and characteristics of Jiaodong red culture, so as to make Jiaodong red culture become the source and driving force of economic and social development in Jiaodong area ${ }^{[4]}$.

\subsection{Characteristics of red culture in Jiaodong}

Spirit is the core of culture. The spirit of different cultures has its own characteristics. The systematic excavation and sorting of relevant materials of Jiaodong red culture, as well as the detailed and in-depth research on the specific fields of Jiaodong red culture on this basis, are the important premise and foundation for refining and refining the characteristics of Jiaodong red culture.

The spiritual characteristics of the Jiaodong people are the formation of the Communist Party of Jiaodong under the guidance of Marx doctrine, the inheritance of the essence of their traditional culture and the improvement of modern western culture ${ }^{[5]}$. Looking at the history of Jiaodong culture, from ancient times to modern times and then to modern times, especially in modern times, innovation and progress are consistent. Innovation and progress are not only one of the spiritual characteristics of Jiaodong red culture, but also the core of the spiritual characteristics of Jiaodong red culture ${ }^{[6]}$. With vivid, concise, vivid and lively language to condense and improve the revolutionary spirit of Jiaodong as the core, we can see richness in simplicity and profundity in popularity, so as to play the role of seeing the big from the small and passing on the macro from the small.

\section{THE SIGNIFICANCE OF INHERITING JIAODONG RED CULTURE}

Among the characteristics embodied in Jiaodong red culture, this clearly oriented revolutionary culture, rooted in the national culture of Chinese civilization and an open culture closely following the pace of the times, can inspire people to strengthen their ideals and beliefs, gather people to devote themselves to economic and social development, and guide people to face the world and the future with a more open and inclusive attitude.

\subsection{Jiaodong red culture plays an important role in strengthening people's ideals and beliefs}

Comrade Xi Jinping said that a country, a nation and a political party must establish and adhere to clear ideals and beliefs at all times and under any circumstances ${ }^{[7]}$. No matter how the society develops, no matter how prosperous the economy is, if we give up the pursuit of lofty ideals and beliefs, our country and nation will not be able to stand tall in the world ${ }^{[8]}$. For Jiaodong region, carrying out the construction of Jiaodong red culture can better inherit and carry forward the fine traditions of Jiaodong people, unswervingly listen to and follow the party, and further strengthen their confidence in the road, theory and system of socialism with Chinese characteristics.

\subsection{Jiaodong red culture is of great significance to promote economic and social development}

Economic construction is the center and cultural construction is the soul. Culture is the key to maintaining the lasting competitiveness of a country and a region. It is a powerful spiritual force to unite and unite the majority of Party members, cadres and the masses. It is an important symbol of regional soft power ${ }^{[9]}$. Carry out the construction of Jiaodong red culture, give full play to the advantages of Jiaodong cultural tradition, cultural resources, cultural strength and cultural potential, and enhance the self-confidence, pride and mission of the majority of Party members, cadres and the masses, which is conducive to further promote the construction of economic, political, cultural, social and ecological civilization in Jiaodong and take the lead in scientific and harmonious development in the new round of regional competition.

\subsection{Jiaodong red culture is an important carrier to promote the development of advanced culture}

Red culture is one of the important sources of socialist advanced culture. It contains rich revolutionary spirit and profound historical and cultural accumulation $^{[10]}$. Its development and innovation is of great significance to vigorously promote the construction of socialist advanced culture. As a product of a specific historical period, red culture not only means the prominent cohesion and incentive role in the revolutionary war, but also the unity of history and times. Even in today's harmonious development, it is still the strongest voice of the times and an important part of the Chinese national spirit.

\subsection{Jiaodong red culture is the realistic need of revolutionary spirit and historical research}

In the history of the Chinese revolution, many major battles had the contributions and sacrifices of the Jiaodong people. The people of Jiaodong provided comprehensive and powerful support for the Chinese revolution, provided huge human, financial and material 
resources for the Chinese revolution, and played an important role in the continuous victory of the Chinese revolution $^{[11]}$. During the war, military civilian integration increased the historical massiness of Jiaodong red culture and the historical pride of the people. At the same time, it also called on us to continue to carry forward the revolutionary spirit of Jiaodong people and carry out in-depth research and construction on the history of Jiaodong red culture.

\section{DEVELOPMENT AND PROMOTION OF RED CULTURE IN JIAODONG}

As an advanced culture guided by Marxism, red culture can guide people to consciously practice socialist core values. Giving full play to the leading role of red culture construction is an inevitable requirement for the Communist Party of China to promote national development and social progress.

\subsection{Firm ideals are the soul of Jiaodong's revolutionary spirit}

The ideal of Communists is a lofty ideal of communism and socialism, unlimited loyalty to the cause of the party and the people, and a firm belief in national liberation and people's happiness ${ }^{[12]}$. At any time and under any circumstances, firm ideals are the most important spiritual support for the Communists and the people to win. The revolutionary spirit of Jiaodong has a firm political position of following the party and loving the country, which is the most important reason for the victory of Jiaodong revolutionary struggle.

The history of Jiaodong revolution and the struggle of the whole Chinese nation tell us that ideals and beliefs cannot be lost, and if they are lost, they will not be Communists. The belief in Marxism, socialism with Chinese characteristics and communism has always been the political soul of Communists and the spiritual pillar for Communists to withstand any test.

\subsection{The unity of the party and the masses is the core of Jiaodong's revolutionary spirit}

The Communist Party of China armed with Marxism is based on the fundamental interests of the overwhelming majority of the people. The only purpose of the party is to serve the people wholeheartedly. The interests of the party are consistent with the interests of the people ${ }^{[13]}$. Under the leadership of the party, the army and the people of Jiaodong can develop and grow in the harsh environment. Therefore, following the party, being with the people, and the unity of the party and the masses is both a position and a direction, which every Communist must always bear in mind.

\subsection{Daring to be first is the main line of Jiaodong's revolutionary spirit}

The pursuit consciousness of daring to compete for the first reflects the party's leading people to take the lead in establishing the party organization and actively carrying out the party's activities during the revolutionary struggle in Jiaodong, which made Jiaodong go ahead of other regions in Shandong during the democratic revolution. Secondly, the sense of daring to compete for the first is also a true portrayal of the earth shaking changes in the economic and social development of Jiaodong after the founding of the people's Republic of China, especially since the reform and opening up ${ }^{[14]}$. It is this consciousness that makes Jiaodong a rare old revolutionary base area and an economically developed area in China.

\subsection{Selfless dedication is the theme of Jiaodong revolutionary spirit}

Since ancient times, the people of Jiaodong have had a fine tradition of friendly cooperation, unity and mutual assistance. During the revolutionary war, the army and the people in Jiaodong area loved the country and the party, took into account the overall situation, had the courage to take responsibility, and had the courage to sacrifice for the overall interests. Everywhere in Jiaodong, there is an upsurge of selfless dedication, and many touching and tearful examples are spread. The people of Jiaodong pushed the unicycle with their hands and feet, launched the victory of the Huaihai Campaign, the victory of the river crossing campaign, and a brand-new people's Republic.

\section{CONCLUSION}

Red resources, red highlights and red classics are the concentrated embodiment of the red spirit. Only by reflecting the red spirit can they attract, shock and inspire people. On the whole, the inheritance and development of Jiaodong red plot culture gene is a long-term and complex theoretical project, which requires in-depth and lasting research and discussion in the academic community, as well as social contributions and concerted efforts. It is hoped that more people of insight will pay attention to this topic and make the revolutionary spirit of Jiaodong, a valuable spiritual wealth, play its due cohesive Role in the great journey of national rejuvenation.

\section{AUTHORS' CONTRIBUTIONS}

Qiong Zhang: Conceptualization, Methodology, Writing - original draft, Visualization, Writing - review \& editing. 


\section{REFERENCES}

[1] Jingyi Wang. Strengthening the protection and inheritance of Red Cultural Heritage [n]. China Heritage daily, 2021-02-26 (007)

[2] Mingjie Liu. Inheriting Jiaodong red soul and condensing development energy [J]. Times report, 2021 (01): 106-107

[3] Wei Zhang. Research on the development and integration path of Jiaodong red cultural resources in the new era [J]. Journal of the Party School of Jinan municipal Party committee, 2020 (04): $100-105$

[4] Ying Wang. Research on the external communication of Jiaodong culture from the perspective of internationalization [J]. Writer world, 2020 (15): 190-191

[5] Zhen Wei. The "three dimensions" of Jiaodong red culture in promoting mainstream ideological identity $[\mathrm{J}]$. Journal of Shengli college, China University of petroleum, 2019,33 (03): 73-76

[6] Quansheng Li. A review of Jiaodong red culture research [J]. Cultural and educational materials, 2019 (23): 82-83

[7] Lihua Yang, sun Meng. Practical significance of carrying forward Jiaodong red culture in the new era [J]. Reading abstracts, 2019 (12): 63-64

[8] Wen Lu, sun Meng. Research on the connotation of Jiaodong red culture [J]. Educational modernization, 2019,6 (50): 222-223

[9] Bintang Wang. Inheriting the red gene and building a red cultural highland in Jiaodong [J]. Party School of the CPC Qingdao Municipal Committee. Journal of Qingdao Institute of administration, 2019 (01): 97-100

[10] Jingyang Diao. Research on the value and practice of Jiaodong red culture in party spirit education under the background of the new era -- Taking Jiaodong (Yantai) party spirit education base as an example [J]. Modern communication, 2018 (20): 80-81

[11] Bintang Wang. Inheriting the red gene and building a red cultural highland in Jiaodong [J]. Party School of the CPC Qingdao Municipal Committee. Journal of Qingdao Institute of administration, 2019 (01): 97-100

[12] Zhenyan Zhou. Carry forward the revolutionary spirit, gather the driving force and build Jiaodong red culture inheritance demonstration area [J]. Friends of Party members and cadres, 2017 (12): 19
[13] Our commentator. Let the red gene be passed on from generation to generation [n]. Yantai daily, July 20, 2017 (001)

[14] Ping Li. Genetic characteristics and contemporary value of Jiaodong red culture [J]. Journal of Yantai Vocational College, 2016,22 (04): 1-3 + 30 